\title{
PENINGKATAN MOTIVASI DAN PRESTASI BELAJAR OPERASI HITUNG BILANGAN BULAT SISWA KELAS 4 MELALUI MEDIA VISUAL INTERAKTIF
}

\author{
Erni Dwi Endarwati dan Djamilah Bondan Widjajanti \\ SDN Paliyan IV Gunungkidul ${ }^{1)}$, Universitas Negeri Yogyakarta \\ Email: erny.tambayong@gmail.com
}

\begin{abstract}
Abstrak
Penelitian ini bertujuan untuk meningkatkan motivasi belajar dan prestasi belajar operasi hitung bilangan bulat siswa kelas IV SD Negeri Paliyan 4 Kecamatan Paliyan Kabupaten Gunungkidul melalui media visual interaktif. Jenis penelitian ini adalah penelitian tindakan kelas yang dilaksanakan dalam dua siklus.Penelitian ini dilaksanakan pada bulan Januari 2015. Subjek penelitian adalah seluruh siswa kelas 4 yang berjumlah 20 siswa. Data penelitian dikumpulkan melalui observasi, tes tulis, angket, dan dokumentasi. Hasil penelitian menunjukkan bahwa media visual interaktif dapat meningkatkan motivasi dan prestasi belajar operasi hitung bilangan bulat siswa kelas 4 .
\end{abstract}

Kata kunci : motivasi, prestasi belajar, operasi hitung bilangan bulat, media visual interaktif

\section{IMPROVING MOTIVATION AND INTEGER ARITHMETIC OPERATION LEARNING ACHIEVEMENT OF THE $4^{\text {th }}$ GRADE STUDENTS THROUGH INTERACTIVE VISUAL MEDIA}

\begin{abstract}
This research aims to improve motivation and learning achievement of integer arithmetic operations of the $4^{\text {th }}$ grade students of SD Paliyan IV Gunungkidul through interactive visual media. The research was a Classroom Action Research study. The study was conducted in two cycles. This research was conducted in SDN Paliyan IV Paliyan Gunungkidul in January 2015. The subjects were all students of the $4^{\text {th }}$ grade consisting of 20 students. The data were collected using observation, paper and pencil tests, questionnaires, and documentation. The results reveals that interactive visual media could improve the students' motivation and learning achievement of integer arithmetic operations of the $4^{\text {th }}$ grade students.
\end{abstract}

Keywords: motivation, learning achievement, integer arithmetic operations, interactive visual media

\section{PENDAHULUAN}

Sekolah Dasar (SD) adalah jenjang pendidikan formal yang paling awal. SD mengemban misi dasar dalam rangka ikut serta mencapai tujuan pendidikan nasional. Pada jenjang SD dilakukan penanaman konsep awal. Penanaman konsep harus sesuai dengan perkembangan siswa dan kurikulum yang berlaku.

Kurikulum yang berlaku di SD adalah kurikulum 2013. Berdasarkan pada kurikulum tersebut pembelajaran pada tingkat SD menggunakan pendekatan tematik integratif. Pembelajaran integratif merupakan pendekatan antar disiplin ilmu (Fogarty, 1991, p.76). Integrasi dari berbagai disiplin ilmu dan kecocokan dibuat dalam tema yang sama.

Salah satu muatan yang diajarkan di SD dalam pembelajaran tematik integratif adalah matematika. Matematika merupakan cabang ilmu yang berperan penting dalam kehidupan sehari-hari (Haylock dan Thangata, 2007, p.3). Dalam rangka pen- 
guasaan dan mengembangkan teknologi di masa depan diperlukan penguasaan matematika yang kuat sejak dini. Kemajuan pesat dibidang teknologi informasi dan komunikasi dewasa ini pun dilandasi oleh perkembangan matematika. Itulah sebabnya matematika diajarkan sejak Sekolah Dasar.

Para siswa diharapkan untuk menguasai matematika agar dapat menerapkannya dalam kehidupan sehari-hari saat memecahkan masalah baik sekarang maupun masa yang akan datang. Salah satu konsep matematika yang harus dikuasai adalah operasi hitung bilangan bulat. Kompetensi tentang operasi hitung bilangan bulat di kelas 4 dikembangkan menjadi: (1) membaca dan menuliskan lambang bilangan bulat, (2) melakukan operasi hitung penjumlahan dan pengurangan, (3) melakukan hitung campuran yang melibatkan operasi hitung penjumlahan dan pengurangan, (4) menyelesaikan masalah matematika yang berhubungan dengan bilangan bulat.

Untuk dapat membantu siswa dalam menguasai konsep tersebut, kualitas pembelajaran matematika harus ditingkatkan. Proses pembelajaran matematika harus memberikan cukup ruang bagi ide, kreativitas dan kemandirian siswa bukan sekedar ditujukan untuk menghafalkan rumus. Kecenderungan pembelajaran matematika hanya pada menghafal rumus dan menerapkannya untuk menyelesaikan soal dirasa kurang menguntungkan siswa, karena akan kesulitan dalam menghadapi persoalan yang memerlukan pemecahan masalah (Widyastuti dan Pujiastuti, 2014, p.184). Pembelajaran matematika di kelas seharusnya ditekankan pada keterkaitan antara konsep-konsep matematika dengan pengalaman anak sehari-hari (Budiharti dan Jailani, 2014, P.29). Proses pembelajaran juga harus bersifat interaktif, menyenangkan, menantang siswa untuk berpartisipasi aktif sehingga siswa dapat termotivasi.
Motivasi didefinisikan sebagai proses dimana tujuan diarahkan, kegiatan dipertahankan dan berkelanjutan (Schunk et al, 2010, p.4). Dalam konteks kelas, konsep motivasi siswa digunakan untuk menjelaskan sejauh mana siswa berinvestasi perhatian dan usaha dalam berbagai kegiatan sesuai dengan yang diinginkan oleh guru mereka (Brophy, 2010, p.3). Motivasi siswa berakar pada pengalaman subyektif siswa, terutama yang terhubung dengan kesediaan mereka untuk terlibat dalam kegiatan belajar dan alasan mereka untuk melakukannya sehingga motivasi belajar harus selalu dipertahankan.

Froiland, Oros dan Smith et al (2012, p.94) mengungkapkan bahwa matematika dapat menjadi mata pelajaran yang sulit danmotivasi intrinsik dapat memberikan energipada siswa untuk menjadi sukses. Oleh karena itu diperlukan berbagai cara untuk dapat meningkatkan motivasi belajar matematika. Salah satu cara untuk memotivasi siswa dalam belajar matematika adalah mengajar matematika dengan cara yang menarik (Tella, 2007, p.7). Dengan cara yang menarik diharapkan akan menjaga (1) perhatian, (2) relevansi, (3) keyakinan, (4) kepuasan yang akhirnya akan mempertahankan motivasi belajar siswa (Rodgers dan Withrow-Thorton, 2005: p.334).

Motivasi mempengaruhi pencapaian prestasi belajar siswa. Bester dan Brand (2010, p.12), Broussard dan Garrison (2004, p.106), Awan, Noureen dan Naz (2011, p.72), serta penelitan Sikhwari (2014, p.24) menemukan bahwa jika siswa termotivasi untuk belajar dan berkonsertrasi, maka prestasi meningkat lebih tinggi. Oleh karena itu guru harus dapat melakukan pembelajaran yang dapat memotivasi siswa sehingga prestasi belajarnya juga dapat meningkat.

Prestasi belajar berhubungan dengan tujuan pembelajaran yaitu pengetahuan dan keterampilan apa yang diharapkan untuk dipelajari siswa yang ditentukan 
melalui proses pertimbangan dan penilaian (Briggs et al, 2009, p.8). Penilaian prestasi belajar oleh pendidik mencakup kompetensi sikap, pengetahuan, dan keterampilan.

Kompetensi sikap berhubungan dengan minat dan sikap siswa yang dapat berbentuk tanggung jawab, kerja sama, disiplin, komitmen, percaya diri, jujur, menghargai pendapat orang lain, dan kemampuan mengendalikan diri. Kompetensi pengetahuan meliputi ingatan, pemahaman, penerapan, analisis, sintesis, dan evaluasi.Kompetensi keterampilan adalah hasil belajar afektif dan kognitif dalam bentuk perilaku atau perbuatan. Kunandar (2014, p.100). Membantu siswa menguasai ketiga kompetensi tersebut proses pembelajaran harus sesuai dengan perkembangan siswa.

Perkembangan siswa SD berada pada tahap operasional konkrit. Mereka akan lebih mudah belajar jika bahan ajar dilengkapi dengan materi, ilustrasi, contoh, dan latihan. Cara yang dapat ditempuh diantaranya adalah dengan memilih media pembelajaran yang sesuai dan menarik misalnya penyajian secara visual.

Visual dapat menunjukkan benda nyata atau abstrak, menggambarkan prosedur, memberikan contoh, mengidentifikasi bagian, dan menarik perhatian serta memancing kegiatan penyelidikan (Newby et al, 2011, p.121). Smaldino, Lowther dan Russel (2014, p.235) menambahkan bahwa visual bisa memotivasi para pembelajar.

Penggunaan media visual lebih efektif jika siswa langsung berinteraksi dengan melakukan percobaan serta mendapat umpan balik. Untuk mendapatkan umpan balik secara langsung diperlukan media visual interaktif. Haney dan Ullmer dalam Yusuf Hadi Miarso (2009, p.462) menjelaskan bahwa karakteristik media interaktif adalah siswa tidak hanya memerhatikan penyajian, atau objek, tetapi dipaksa untuk berinteraksi selama mengikuti pelajaran.
Media visual interaktif adalah suatu media yang dapat dikontrol pengoperasiannya oleh siswa yang berisi tentang materi tertentu dan disajikan dalam bentuk teks, gambar, animasi. Media visual interaktif diharapkan mampu membantu siswa lebih aktif, termotivasi dan interaktif serta menambah pengalaman belajar siswa.

Dalam kenyataan di SD Negeri Paliyan IV Kecamatan Paliyan Kabupaten Gunungkidul, kegiatan pembelajaran berdasarkan standar proses kurikulum 2013 belum sepenuhnya sesuai dengan yang diharapkan. Berdasarkan observasi yang dilakukan pada akhir bulan Agustus dan hingga awal September 2014 ditemukan fakta bahwa motivasi belajar siswa masih rendah. Hal ini dibuktikan dengan adanya siswa yang kurang bersemangat dalam belajar, cepat merasa bosan dan mengeluh saat mendapatkan tugas dari guru.

Rendahnya motivasi belajar menyebabkan prestasi belajarnya juga rendah. Data menunjukkan bahwa prestasi belajar siswa tentang operasi hitung bilangan bulat pada tahun ajaran 2014/2015 masih rendah. Untuk aspek pengetahuan, siswa yang tuntas dengan KKM 70 sebanyak 9 siswa (45\%) dan untuk aspek keterampilan, siswa yang tuntas dengan KKM 68 sebanyak 7 siswa (35\%). Hal tersebut juga diperkuat dengan data dua tahun terakhir menunjukkan prestasi belajar yang rendah pada kompetensi yang sama.

Dari permasalahan kelas tersebut penelitian ini difokuskan pada peningkatkan motivasi dan prestasi belajar kompetensi matematika tentang operasi hitung bilangan bulat melalui media visual interaktif pada siswa kelas 4 SD Negeri Paliyan IV Kecamatan Paliyan Kabupaten Gunungkidul Tahun Pelajaran 2014/2015. Rumusan masalah diantaranya: 1) Bagaimana peningkatan motivasi belajar siswa kelas 4 setelah dilakukan pembelajaran menggunakan media visual interaktif?; 2) Bagaimana peningkatan prestasi belajar operasi hitung bilangan bulat siswa kelas 
4 setelah dilakukan pembelajaran menggunakan media visual interaktif?.

Penelitian ini bertujuan untuk meningkatkan motivasi belajar melalui media visual interaktif, yang pada gilirannya akan meningkatkan prestasi belajar operasi hitung bilangan bulat siswa kelas 4 di SDN Paliyan IV, Gunungkidul.

Penelitian ini memberikan manfaat bagi siswa, guru, dan sekolah. Untuk siswa penelitian ini memberikan manfaat diantaranya: (1) memberikan pengalaman belajar yang baru dalam mempelajari operasi hitung bilangan bulat, (2) menjadikan siswa lebih aktif di kelas, (3) berinteraksi langsung dengan materi sehingga dapat menemukan konsep, (4) lebih bersemangat, (5) prestasi belajar meningkat. Untuk guru diantaranya: (1) dapat dijadikan bahan pertimbangan guru dalam merencanakan pembelajaran matematika, (2) meningkatkan kreativitas guru dalam mengajarkan konsep matematika, (3) dijadikan bahan pertimbangan untuk mengadakan penelitian lanjutan. Manfaat bagi sekolah yaitu memberikan kontribusi mutu pendidikan siswa terutama dalam pembelajaran matematika.

\section{METODE}

Jenis Penelitian

Penelitian ini adalahpenelitian tindakan kelas yang dilaksanakan dalam dua siklus. Desain penelitian yang digunakan adalah desain siklus yang dikemukakan oleh Kemmis dan Mc. Taggart seperti pada Gambar 1.

Dari gambar 1 terlihat bahwa setiap siklus terdiri dari perencanaan, pelaksanaan dan observasi, serta refleksi.

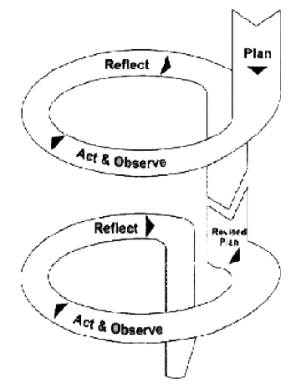

(Sumber: Mc.Taggart, 1993, p. 32)

Gambar 1. Desain Penelitian Tindakan

Kemmis \&Taggart

Waktu Penelitian

Penelitian dilaksanakan di semester II tahun ajaran 2014/2015 yaitu pada bulan Januari 2015.

Tempat Penelitian

Penelitian ini dilaksanakan di kelas 4SD Negeri Paliyan IV Kecamatan Paliyan Kabupaten Gunungkidul.

Subjek Penelitian

Subjek penelitian adalah siswa kelas 4 SD yang berjumlah 20 siswa. yang terdiri dari 11 siswa perempuan dan 9 siswa laki-laki.

Teknik Pengumpulan Data

Teknik pengumpulan data yang digunakan adalah tes dan non tes. Tes digunakan untuk mengukur prestasi belajar siswa aspek pengetahuan dan aspek keterampilan.

Instrumen pengumpulan data berupa tes prestasi belajar pilihan ganda, tes prestasi belajar uraian, rating scale sikap siswa, checklist proses pembelajaran dan angket tertutup motivasi siswa dan kamera.

Teknik analisis data yang digunakan adalah analisis deskriptif. Pendekatan deskriptif ada dua macam yaitu kuantitatif dan kualitatif. Untuk menganalisis data nilai tes prestasi belajar siswa digunakan pendekatan kuantitatif karena datanya berupa nilai siswa. Selanjutnya, data 
disajikan dalam bentuk tabel dan grafik. Sedangkan pendekatan kualitatif digunakan untuk menganalisis data angket dan lembar observasi kegiatan pembelajaran. Untuk selengkapnya tentang analisis data dalam penelitian ini akan dijelaskan sebagai berikut.

Data Hasil Tes Prestasi Belajar Pilihan Ganda

Hasil tes prestasi siswa dianalisis untuk mengetahui prestasi belajar matematika siswa setelah dilakukan pembelajaran operasi hitung bilangan bulat dengan media visual interaktif. Tes prestasi belajar yang mengukur aspek pengetahuan berbentuk pilihan ganda. Nilai siswa dihitung dengan rumus berikut.

$$
\begin{aligned}
& \text { skor siswa } \\
& =\frac{\text { banyak jawaban benar }}{\text { banyak soal }} \times 100 \\
& \text { (Majid dan Firdaus, 2014, p.205) }
\end{aligned}
$$

Siswa dikatakan tuntas jika dapat mencapai KKM sebesar 70. Setelah mendapatkan nilai tes prestasi belajar siswa kemudian dihitung rata-rata kelas menggunakan rumus berikut.

$$
\bar{X}=\frac{\sum X_{i}}{n}
$$

(Kumaidi dan Manfaat, 2013, p.78)

keterangan:

$\mathrm{n}$ = banyaknya anggota (observasi)

$\mathrm{X}=$ mean

$\sum X i=$ jumlah seluruh individual observasi (dalam penelitian ini adalah nilai prestasi belajar)

Langkah selanjutnya yaitu menghitung persentasi ketuntasan belajar pada setiap siklus dengan rumus sebagai berikut.

$\%$ Ketuntasan

$$
=\frac{\text { jumlah siswa yang tuntas }}{\text { jumlah seluruh siswa }} \times 100 \%
$$

Data Hasil Tes Prestasi Belajar Uraian

Tes prestasi belajar berbentuk uraian digunakan untuk megukur prestasi siswa pada aspek keterampilan. Tes tertulis yang digunakan berbentuk uraian objektif. Dalam penelitian ini total skor tiap butir soal adalah 4 sehingga skor maksimal adalah 5 x $4=20$. Nilai masing-masing siswa dihitung menggunakan rumus di bawah ini.

$$
\text { Skor siswa }=\frac{\text { Skor yang diperole } h}{\text { Skor maksimal }} \times 100
$$

(Majid dan Firdaus, 2014, p.210)

Berdasarkan pada Permendikbud No. 104 tahun 2014 siswa dinyatakan tuntas dalam aspek keterampilan jika mempunyai nilai dengan kriteria baik. Kriteria baik berada pada rentang 66 - 70. Dalam penelitian ini ketuntasan prestasi belajar aspek keterampilan ditetapkan sebesar 68. Persentase siswa yang tuntas dengan kriteria yang sudah ditetapkan adalah sebagai berikut.

$$
\frac{\text { jumlah peserta didik yang tuntas }}{\text { jumlah seluruh peserta didik }} \times 100 \%
$$

Rating Scale sikap siswa

Pada rating scale sikap siswa terdapat 2 sikap yang diamati yaitu rasa ingin tahu dan tanggung jawab. Setiap sikap mempunyai 3 aspek kompetensi. Sedangkan setiap kompetensi mempunyai 1 indikator. Masing-masing indikator mempunyai 4 pilihan alternatif nilai.Nilai 4 berarti baik sekali, 3 berarti baik, 2 berarti cukup dan 1 berarti kurang. Skor tertinggi adalah $4 \mathrm{x}$ $6=24$. Skor siswa dihitung menggunakan rumus sebagai berikut.

$$
\text { Skor siswa }=\frac{\text { skor perole han }}{\text { skor tertinggi }} \times 4
$$

(sumber: Majid dan Firdaus, 2014, p.182)

Sesuai permendikbud No. 104 Tahun 2014 siswa memperoleh nilai akhir untuk aspek afektif/sikap diambil dari nilai modus. Skor siswa dihitung setiap per- 
temuan kemudian pada akhir siklus dicari modusnya. Skor modus yang digunakan adalah 1,00-4,00 dengan predikat Kurang (K), Cukup (C), Baik (B), dan Sangat Baik (SB), dengan konversi seperti pada tabel 1 sebagai berikut:

Tabel 1. Tabel Konversi Skor dan Predikat Untuk Aspek Sikap

\begin{tabular}{|c|c|c|}
\hline Modus & $\begin{array}{c}\text { Rentang } \\
\text { Skor }\end{array}$ & Predikat \\
\hline 4,00 & $3,51-4,00$ & $\begin{array}{l}\text { Sangat Baik } \\
\text { (SB) }\end{array}$ \\
\hline 3,00 & $2,51-3,50$ & Baik (B) \\
\hline 2,00 & $1,51-2,50$ & Cukup (C) \\
\hline 1,00 & $1,00-1,50$ & Kurang (K) \\
\hline
\end{tabular}

Persentase jumlah siswa dalam masingmasing predikat dengan rumus berikut.

$$
\frac{\text { jumlah siswa dalam predikat }}{\text { jumlah seluruh siswa }} \times 100 \%
$$

Data hasil angket tertutup motivasi siswa

Untuk mendeskripsikan motivasi siswa dalam pembelajaran matematika digunakan angket tertutup. Jumlah pernyataan untuk mengukur motivasi belajar siswa adalah 20. Pernyataan dengan pilihan jawaban "ya" atau "tidak". Skor yang diberikan adalah 1 dan 0 . Untuk pernyataan positif jawaban "ya" diberi skor 1, dan jawaban "tidak" diberi skor 0. Sedangkan untuk pernyataan negatif jawaban "ya" diberi skor 0, dan jawaban "tidak" diberi skor 1. Skor angket per siswa dapat dihitung dengan menggunakan rumus berikut.

$$
T=\frac{\text { Skor Perolehan }}{\text { Skor total }} \times 100
$$

Setelah dilakukan penghitungan skor untuk setiap siswa, selanjutnya dikategorikan berdasarkan skor yang diperoleh. Pengkategorian didasarkan pada ketentuan dalam tabel 2 sebagai berikut.
Tabel 2. Kategori Motivasi Belajar Siswa

\begin{tabular}{cc}
\hline Skor angket siswa & Kategori \\
\hline $80<\mathrm{T} \leq 100$ & Sangat baik \\
$60<\mathrm{T} \leq 80$ & Baik \\
$40<\mathrm{T} \leq 60$ & Cukup baik \\
$20<\mathrm{T} \leq 40$ & Kurang baik \\
$0<\mathrm{T} \leq 20$ & Sangat kurang \\
\hline
\end{tabular}

(Sumber: Widoyoko, 2012, p.115)

Selanjutnya dilakukan penghitungan persentase siswa dalam tiap kategori. Cara menghitung persentase tersebut adalah sebagai berikut.

$$
\frac{\text { jumlah siswa dalam kategori }}{\text { jumlah seluruh siswa }} \times 100 \%
$$

\section{Checklist proses belajar mengajar}

Observasi dilakukan untuk mengamati proses belajar mengajar. Dalam checklist proses pembelajaran terdapat 2 alternatif jawaban yaitu "ya" dan "tidak". Jawaban "ya" diberi skor 1 (satu) sedangkan jawaban "tidak" diberi skor 0 (nol). Skor maksimal adalah 20.Kemudian untuk mengukur keterlaksanaan pembelajaran dihitung persentasenya menggunakan rumus sebagai berikut.

$$
\text { Persentase }(\mathrm{P})=\frac{\text { skor perole han }}{\text { skor maksimal }} \times 100 \%
$$

Selanjutnya hasil persentase tersebut dikategorikan berdasarkan Tabel 3 .

Tabel 3. Interpretasi Persentase Keterlaksanaan Pembelajaran

\begin{tabular}{cc}
\hline $\begin{array}{c}\text { Persentase Skor yang } \\
\text { Diperoleh }\end{array}$ & Kategori \\
\hline $90<\mathrm{AB} \leq 100$ & Amat Baik (AB) \\
$80<\mathrm{B} \leq 90$ & Baik (B) \\
$70<\mathrm{C} \leq 80$ & Cukup (C) \\
$\leq 70$ & Kurang (K) \\
\hline
\end{tabular}

(Sumber: Depdikbud, 2014)

Kriteria keberhasilan penelitian diukur dengan minimal (1) 70\% siswa mempunyai 
motivasi belajar dalam kategori minimal baik, (2) 75\% siswa mempunyai prestasi belajar aspek sikap dalam predikat minimal baik yaitu mempunyai nilai modus 3 dari semua aspek yang diamati, (3) 75\% siswa telah tuntas pada prestasi belajar aspek pengetahuan dengan KKM 70 dan (4) $75 \%$ siswa telah mencapai prestasi belajar aspek keterampilan dalam kategori minimal baik dengan KKM 68.

\section{HASIL DAN PEMBAHASAN}

Hasil Penelitian

Sebelum Penelitian

Sebelum penelitian dilakukan observasi terlebih dahulu mengenai motivasi dan prestasi belajar tentang operasi hitung bilangan bulat di kelas 4 SD Negeri Paliyan IV Gunungkidul. Berdasarkan hasil observasi tersebut diperoleh hasil diantaranya: (1) motivasi belajar siswa masih rendah dan (2) prestasi belajar operasi hitung bilangan bulat juga masih rendah. Hasil analisis angket tersaji dalam Tabel 4 .

Tabel 4. Hasil Analisis Angket Pra Tindakan

\begin{tabular}{|c|c|c|c|c|c|c|c|}
\hline \multirow[b]{2}{*}{$\underbrace{\frac{E}{E}}}$. & \multirow[b]{2}{*}{ 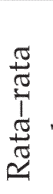 } & \multirow[b]{2}{*}{$\frac{\stackrel{v}{0}}{\dot{w}}$} & \multicolumn{5}{|c|}{ Kategori } \\
\hline & & & 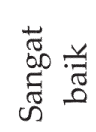 & $\begin{array}{l}\frac{V}{\pi} \\
\text { صี }\end{array}$ & $\underset{\vec{z}}{\tilde{J}}$ & 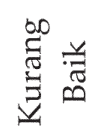 & 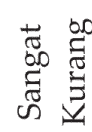 \\
\hline \multirow{2}{*}{20} & \multirow{2}{*}{\multicolumn{2}{|c|}{54,75}} & 0 & 8 & 9 & 3 & 0 \\
\hline & & & siswa & siswa & siswa & siswa & siswa \\
\hline
\end{tabular}

Prestasi belajar matematika untuk operasi hitung bilangan bulat juga masih rendah. Hal ini ditunjukkan dengan kurang maksimalnya nilai tes yang diperoleh siswa. Berdasarkan pada buku daftar nilai yang dimiliki oleh guru diperoleh data seperti pada Tabel 5 .
Tabel 5. Prestasi Belajar Siswa Sebelum Tindakan

\begin{tabular}{cccc}
\hline No & $\begin{array}{c}\text { Prestasi } \\
\text { belajar }\end{array}$ & $\begin{array}{c}\text { Jumlah } \\
\text { siswa }\end{array}$ & $\begin{array}{c}\text { Jumlah } \\
\text { siswa yang } \\
\text { tuntas }\end{array}$ \\
\hline 1. & $\begin{array}{c}\text { Aspek } \\
\text { pengetahuan }\end{array}$ & 20 & 9 \\
2. & $\begin{array}{c}\text { Aspek } \\
\text { keterampilan }\end{array}$ & 20 & 7 \\
\hline
\end{tabular}

Sebelum pelaksanaan siklus I dimulai dilaksanakan persiapan untuk mengkopi dan mengecek media visual interaktif yang akan digunakan pada setiap komputer atau laptop yang akan digunakan oleh siswa. Guru juga mengajak siswa untuk mencoba mengoperasikan komputer terutama dalam menggunakan laptop yang sedikit berbeda dengan komputer.

\section{Siklus I}

Tahapan pertama yang dilakukan adalah perencanaan. Hasil dari perencanaan tersebut adalah sebagai berikut: (1) tersusunnya jadwal penelitian, (2) tersusunnya Rencana Pelaksanaan Pembelajaran (RPP), (3) tersusunnya Lembar Kegiatan Siswa (LKS), (4) tersedianya media visual interaktif, (5) tersusunnya kisi-kisi dan soal tes prestasi belajar pilihan ganda siklus I, (6) tersusunnya rating scale sikap siswa, (7) tersusunnya kisi-kisi dan soal tes prestasi belajar berbentuk uraian, (8) tersusunnya angket tentang motivasi, (9) tersusunnya checklist proses pembelajaran.

Keterlaksanaan Pembelajaran

Berdasarkan hasil observasi melalui checklist proses pembelajaran pada pertemuan I keterlaksanaan pembelajaran mencapai $85 \%$ dan pada pertemuan II dan III mencapai 90\%. Jadi, dapat dikatakan bahwa proses pembelajaran pada setiap pertemuan di siklus I berada dalam kategori baik. 
Hasil Angket Motivasi Siswa

Pada akhir siklus I, siswa mengisi angket motivasi belajar. Hasil dari pengisian angket dalam Tabel 6 .

Tabel 6. Hasil Angket Motivasi Siswa Siklus I

\begin{tabular}{ccc}
\hline Kategori & Jumlah & Persentase \\
Motivasi & Siswa & \\
\hline Sangat baik & 0 & $0 \%$ \\
Baik & 14 & $70 \%$ \\
Cukup baik & 5 & $25 \%$ \\
Kurang baik & 1 & $5 \%$ \\
Sangat kurang & 0 & $0 \%$ \\
\hline
\end{tabular}

Rating Scale Sikap Siswa

Rating scale sikap siswa digunakan untuk menilai sikap siswa. Sikap siswa yang dinilai antara lain rasa ingin tahu dan bertanggungjawab. Hasil dari penilaian sikap siswa pada siklus I dapat dilihat pada Tabel 7.

Tabel 7. Hasil penilaian sikap siswa siklus I

\begin{tabular}{cccc}
\hline Modus & Predikat & $\begin{array}{c}\text { Jumlah } \\
\text { siswa }\end{array}$ & $\%$ \\
\hline 4 & Sangat Baik & 0 orang & $0 \%$ \\
& (SB) & & \\
3 & Baik (B) & 15 orang & $75 \%$ \\
2 & Cukup (C) & 5 orang & $25 \%$ \\
1 & Kurang (K) & 0 orang & $0 \%$ \\
\hline
\end{tabular}

Hasil Tes Prestasi Pilihan Ganda

Tes prestasi belajar yang berbentuk pilihan ganda digunakan untuk mengukur prestasi belajar aspek pengetahuan. Hasil tes setelah tindakan pada siklus I tersaji dalam Tabel 8.

Tabel 8. Hasil tes prestasi belajar aspek pengetahuan pada siklus I

\begin{tabular}{cccc}
\hline No & Kategori & $\begin{array}{c}\text { Jumlah } \\
\text { siswa }\end{array}$ & Persentase \\
\hline 1 & Tuntas & 15 & $75 \%$ \\
2 & Belum Tuntas & 5 & $25 \%$ \\
& Jumlah & 20 & $100 \%$ \\
\hline
\end{tabular}

Hasil Tes Prestasi Uraian

Prestasi belajar aspek keterampilan diukur menggunakan tes yang berbentuk uraian. Keterampilan yang diukur adalah keterampilan memecahkan masalah yang berkaitan dengan operasi hitung bilangan bulat. Persentase siswa yang tuntas dan belum tuntas pada aspek keterampilan tersaji dalam Tabel 9.

Tabel 9. Prestasi Belajar Aspek Keterampilan Pada Siklus I

\begin{tabular}{cccc}
\hline No & Kategori & $\begin{array}{c}\text { Jumlah } \\
\text { siswa }\end{array}$ & Persentase \\
\hline 1 & Tuntas & 14 & $70 \%$ \\
2 & Belum Tuntas & 6 & $30 \%$ \\
& Jumlah & 20 & $100 \%$ \\
\hline
\end{tabular}

\section{Refleksi}

Proses refleksi dilakukan oleh guru kelas 4 selaku kolaborator bersama peneliti dan satu guru lain sebagai observer setelah tindakan pada siklus I selesai. Hasil refleksi antara lain sebagai berikut.

Pertama, motivasi belajar pada siklus I menunjukkan sebanyak 70\% siswa memiliki motivasi belajar dalam kategori baik. Artinya sudah mencapai kriteria keberhasilan yang ditetapkan dalam penelitian ini yaitu minimal $70 \%$ siswa mempunyai motivasi belajar dalam kategori minimal baik. Hal tersebut juga menunjukkan adanya peningkatan jika dibanding dengan hasil pengisian angket sebelum tindakan yaitu sebesar $30 \%$.

Kedua, prestasi belajar siswa aspek sikap pada siklus I menunjukkan sebanyak $75 \%$ siswa mempunyai sikap dalam predikat baik. Artinya sudah mencapai kriteria keberhasilan yang ditetapkan dalam penelitian ini yaitu minimal $75 \%$ siswa memiliki sikap dalam predikat minimal baik.

Ketiga, prestasi belajar siswa aspek pengetahuan pada siklus I menunjukkan sebanyak $75 \%$ siswa tuntas dengan KKM 70. Dengan demikian sudah mencapai 
kriteria keberhasilan yang ditetapkan. Hal tersebut juga menunjukkan adanya peningkatan prestasi belajar aspek pengetahuan dari hasil sebelum tindakan sebesar $30 \%$.

Keempat, prestasi belajar siswa aspek keterampilan pada siklus I menunjukkan sebanyak $70 \%$ siswa memiliki keterampilan dalam kriteria baik. Hal tersebut menunjukkan bahwa belum mencapai kriteria keberhasilan yang ditetapkan dalam penelitian ini yaitu minimal $75 \%$ siswa memiliki prestasi belajar aspek keterampilan. Namun sudah meningkat sebesar $35 \%$ dari hasil sebelum tindakan.

Pada dasarnya proses pembelajaran operasi hitung bilangan bulat menggunakan media visual interaktif di kelas 4 SD Negeri Paliyan IV Gunungkidul telah berjalan dengan baik. Akan tetapi ada beberapa kendala yang dihadapi. Kendala/ masalah tersebut antara lain: (1) ada beberapa siswa yang tidak bisa menggunakan laptop, (2) terjadi permasalahan saat pembagian kelompok, (3) ada kelompok siswa yang tidak mau saling bekerja sama dan didominasi oleh salah satu anggota saja, (4) saat siswa melakukan kesalahan dalam mengerjakan latihan pada media visual interaktif, siswa harus mengulang menjawab dari awal bukan sekedar membetulkan pada bagian yang salah sehingga merepotkan siswa, (5) siswa belum terbiasa menanggapi hasil kerja kelompok lain, (6) guru tidak melaksanakan tindak lanjut dengan memberikan arahan atau kegiatan atau tugas sebagai pengayaan pada pertemuan I dan III, (7) guru tidak menjelaskan cara menggunakan media visual interaktif pada pertemuan II, (8) pada naskah tes prestasi yang berbentuk uraian terdapat adanya kekurangan tempat untuk menjawab.

Adanya beberapa permasalahan yang muncul pada siklus I maka disarankan untuk melakukan perbaikan pada proses tindakan siklus II. Proses perbaikan tersebut diantaranya sebagai berikut: (1) disediakan mouse bagi siswa yang membutuhkan, (2) sebelum pembagian kelompok guru harus memberikan pengertian terlebih dahulu bahwa pada dasarnya semuanya adalah teman, (3) guru harus jeli dalam membagi kelompok supaya tidak ada yang mendominasi, (4) media diatur supaya ketika siswa melakukan pembetulan hanya pada bagian yang salah saja, (5) diperlukan contoh dari guru, (6) memberitahukan pada guru untuk menepati waktu yang telah ditetapkan, (7) guru tetap harus menjelaskan cara menggunakan media, (8) menambah tempat untuk menjawab pada naskah tes prestasi yang berbentuk uraian, (9) perlu diberikan tindak lanjut kepada siswa yang berupa penjelasan dan latihan soal.

\section{Siklus II}

Keterlaksanaan Proses Pembelajaran

Seperti halnya pada siklus I keseluruhan aktivitas guru dan siswa diamati melalui checklist proses pembelajaran. Pada pertemuan I keterlaksanaan pembelajaran mencapai 95\% dan pada pertemuan II dan III mencapai $100 \%$. Dengan demikian dapat dikatakan bahwa proses pembelajaran pada setiap pertemuan di siklus II berada dalam kategori amat baik.

\section{Hasil Angket Motivasi Siswa}

Di akhir siklus II, siswa juga mengisi angket motivasi.Hasil dari pengisian angket motivasi tersebut terangkum dalam Tabel 10.

Tabel 10. Hasil Angket Motivasi Siswa Siklus II

\begin{tabular}{ccc}
\hline Kategori Sikap & $\begin{array}{c}\text { Jumlah } \\
\text { Siswa }\end{array}$ & Persentase \\
\hline Sangat baik & 2 & $10 \%$ \\
Baik & 15 & $75 \%$ \\
Cukup baik & 2 & $10 \%$ \\
Kurang baik & 1 & $5 \%$ \\
Sangat kurang & 0 & $0 \%$ \\
\hline
\end{tabular}


Rating Scale Sikap Siswa

Rating Scale sikap siswa digunakan untuk menilai sikap siswa pada tindakan siklus II. Rangkuman hasil penilaian sikap siswa pada siklus II dapat dilihat pada Tabel 11.

Tabel 11. Hasil Penilaian Sikap Siswa Siklus II

\begin{tabular}{cccc}
\hline Modus & Predikat & $\begin{array}{c}\text { Jumlah } \\
\text { siswa }\end{array}$ & Persentase \\
\hline 4 & $\begin{array}{c}\text { Sangat Baik } \\
\text { (SB) }\end{array}$ & 1 orang & $5 \%$ \\
3 & Baik (B) & 17 orang & $85 \%$ \\
2 & Cukup (C) & 2 orang & $10 \%$ \\
1 & Kurang (K) & 0 orang & $0 \%$ \\
\hline
\end{tabular}

Hasil Tes Prestasi Pilihan Ganda

Tes prestasi berbentuk pilihan ganda digunakan untuk mengukur prestasi belajar aspek pengetahuan. Jumlah butir tes yang diberikan sebanyak 15. Pada akhir siklus II persentase siswa yang tuntas sebanyak $85 \%$ seperti tersaji dalam Tabel 12.

Tabel 12. Hasil Tes Prestasi Belajar Aspek Pengetahuan Siklus II

\begin{tabular}{cccc}
\hline No & Kategori & $\begin{array}{c}\text { Jumlah } \\
\text { siswa }\end{array}$ & Persentase \\
\hline 1 & Tuntas & 17 & $85 \%$ \\
2 & Belum Tuntas & 3 & $15 \%$ \\
& Jumlah & 20 & $100 \%$ \\
\hline
\end{tabular}

Hasil Tes Prestasi Berbentuk Uraian

Tes prestasi berbentuk uraian digunakan untuk mengukur prestasi belajar aspek keterampilan. Prestasi belajar siswa aspek keterampilan pada siklus II selengkapnya dapat dilihat dalam Tabel 13.
Tabel 13. Hasil Tes Prestasi Belajar Aspek Keterampilan Siklus II

\begin{tabular}{cccc}
\hline No & Kategori & $\begin{array}{c}\text { Jumlah } \\
\text { siswa }\end{array}$ & Persentase \\
\hline 1 & Tuntas & 17 & $85 \%$ \\
2 & Belum Tuntas & 3 & $15 \%$ \\
& Jumlah & 20 & $100 \%$ \\
\hline
\end{tabular}

Refleksi

Proses refleksi dilakukan setelah tindakan pada siklus II berakhir. Hasil refleksi antara lain:

Pertama, berdasarkan pengamatan yang dilakukan semua kegiatan pembelajaran yang direncanakan telah terlaksana semua dengan baik.

Kedua, adanya peningkatan motivasi belajar siswa, hal ini terlihat pada Tabel 14.

Tabel 14. Peningkatan Motivasi Belajar Siswa

\begin{tabular}{|c|c|c|c|c|}
\hline Aspek & অ. & $\begin{array}{l}\overrightarrow{0} \\
00 \\
\text { है } \\
\text { E }\end{array}$ & 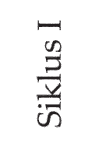 & 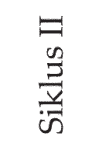 \\
\hline \multirow{3}{*}{ Motivasi } & 8 & 14 & 14 & 17 \\
\hline & siswa & siswa & siswa & siswa \\
\hline & $(40 \%)$ & $(70 \%)$ & $(70 \%)$ & $(85 \%)$ \\
\hline
\end{tabular}

Ketiga, adanya peningkatan prestasi belajar aspek sikap. Hal ini dibuktikan dengan bertambahnya jumlah siswa yang mempunyai sikap dalam predikat minimal baik sebanyak 15\%, dari 75\% (15 siswa) pada siklus I menjadi 90\% (18 siswa) pada siklus II.

Keempat, adanya peningkatan prestasi belajar aspek pengetahuan seperti tersaji dalam Tabel 15. 
Tabel 15. Peningkatan Prestasi Belajar Aspek Pengetahuan

\begin{tabular}{|c|c|c|c|c|}
\hline Aspek & 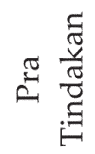 & 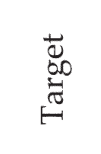 & $\frac{\sqrt[n]{3}}{\sqrt[3]{n}}$ & $\begin{array}{l}\exists \\
y \\
\frac{0}{3} \\
\frac{y}{5}\end{array}$ \\
\hline $\begin{array}{l}\text { Pengetah } \\
\text { uan }\end{array}$ & $\begin{array}{c}9 \\
\text { siswa } \\
(45 \%)\end{array}$ & $\begin{array}{c}15 \\
\text { siswa } \\
(75 \%)\end{array}$ & $\begin{array}{c}15 \\
\text { siswa } \\
(75 \%)\end{array}$ & $\begin{array}{c}17 \\
\text { siswa } \\
(85 \%) \\
\end{array}$ \\
\hline
\end{tabular}

Kelima, adanya peningkatan prestasi belajar aspek keterampilan.Hal ini dibuktikan dengan bertambahnya siswa yang mencapai prestasi belajar aspek keterampilan dalam kriteria minimal baik dengan batas nilai 68 pada setiap siklus seperti pada Tabel 16.

Tabel 16. Peningkatan Prestasi Belajar Aspek Keterampilan

\begin{tabular}{|c|c|c|c|c|}
\hline Aspek & 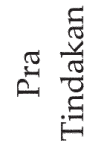 & $\begin{array}{l}\vec{d} \\
\stackrel{0}{0} \\
\text { है }\end{array}$ & $\frac{\sqrt{n}}{3}$ & $\begin{array}{l}\boxminus \\
\frac{n}{z} \\
\frac{y}{5}\end{array}$ \\
\hline $\begin{array}{l}\text { Keteramp } \\
\quad \text { ilan }\end{array}$ & $\begin{array}{c}7 \\
\text { siswa } \\
(35 \%)\end{array}$ & $\begin{array}{c}15 \\
\text { siswa } \\
(75 \%)\end{array}$ & $\begin{array}{c}14 \\
\text { siswa } \\
(70 \%)\end{array}$ & $\begin{array}{c}17 \\
\text { siswa } \\
(85 \%)\end{array}$ \\
\hline
\end{tabular}

Pembahasan

Keterlaksanaan Proses Pembelajaran

Peningkatan proses dan hasil terjadi pada setiap siklus. Hal tersebut dapat dicapai karena persiapan dan pelaksanaan pembelajaran operasi hitung bilangan bulat melalui media visual interaktif pada pembelajaran tematik integratif dilaksanakan guru sesuai tahapan dan langkah-langkah yang tertera pada RPP. Guru secara maksimal merencanakan dan melaksanakan pembelajaran dengan memperhatikan aspek-aspek penting dalam pembelajaran termasuk merancang pembelajaran sesuai dengan materi dan ketersediaan sumber belajar serta media pembelajaran.

Guru juga sangat memperhatikan hasil refleksi dari siklus sebelumnya untuk merencanakan pembelajaran pada siklus berikutnya supaya hasilnya lebih baik. Hal tersebut sesuai dengan pendapat Bahrul Hayat (2011, p.34) bahwa rencana mengajar yang disiapkan guru untuk siklus berikutnya harus didasarkan pada hasil dan umpan balik penilaian sebelumnya. Kegiatan pembelajaran pada siklus II dilakukan sesuai dengan kesepakatan dan hasil refleksi pada siklus I.

Berdasarkan pada hasil refleksi dapat diketahui adanya kekurangan yang terjadi pada pembelajaran sebelumnya sehingga dapat dilakukan perbaikan. Hal ini penting untuk mempertahankan hasil yang sudah diperoleh diantaranya adalah motivasi belajar siswa. Hal-hal yang mungkin dapat menurunkan motivasi belajar harus dihilangkan sementara yang dapat meningkatkan motivasi harus dipertahankan.

Peningkatan Motivasi Belajar Siswa

Kondisi sebelum pembelajaran melalui media visual interaktif, siswa masih menunjukkan kurang termotivasi dalam pembelajaran. Siswa terlihat kurang aktif selama mengikuti pembelajaran, kurang bersemangat, cepat bosan, dan mengeluh saat mendapatkan tugas dari guru. Pada siklus I siswa sudah mulai menunjukkan bahwa mereka termotivasi dalam belajar saat media visual interaktif digunakan. Peningkatan ini terjadi disebabkan karena media visual interaktif dapat menarik perhatian siswa. Seperti yang diungkapkan oleh Nana Sudjana dan Ahmad Rivai (2010, p.2) serta Smaldino, Lowther dan Russel (2014, p.234) bahwa pemakaian media dalam proses belajar mengajar menjadikan pengajaran akan lebih menarik perhatian siswa sehingga dapat menumbuhkan motivasi belajar.

Namun, ada beberapa siswa yang merasa kesulitan menggunakan laptop tanpa bantuan mouse. Ada satu siswa yang mendominasi pada kelompoknya sehingga temannya tidak mendapatkan kesempatan untuk menggunakan media visual 
interaktif.Beberapa siswa juga mengeluh saat membetulkan pekerjaan mereka yang salah pada media sehingga hal tersebut dikhawatirkan dapat menurunkan motivasi belajarnya.Oleh karena itu pada siklus II dilakukan pembagian kelompok yang baru dan media yang dibuat lebih praktis. Saat siswa melakukan kesalahan dan ingin membetulkannya siswa cukup membetulkan pada bagian yang salah saja.

Pada siklus II siswa lebih termotivasi dalam belajar muatan matematika tentang operasi hitung bilangan bulat. Hal ini disebabkan karena sudah terbagi kelompok yang baru, tersedianya mouse dan media dibuat lebih praktis. Siswa terlihat lebih mandiri, bersemangat dan tidak mudah menyerah dalam belajar serta menunjukkan perhatian yang lebih. Seperti yang diungkapkan oleh Williams dan Williams (2012, p.2) bahwa siswa yang mempunyai motivasi dalam belajar akan menunjukkan perhatian lebih serta merasa senang dan bersemangat. Pada saat mereka menjawab latihan yang ada pada media visual interaktif dan ternyata jawaban mereka salah, mereka tidak mengeluh dan mau mengulangnya hingga benar.Hal tersebut menandakan siswa termotivasi dalam belajar. Sesuai dengan pendapat Sardiman (2011, p.102) bahwa salah satu ciri motivasi adalah ulet menghadapi kesulitan dan lebih mandiri.

Selain itu media visual interaktif memungkinkan siswa untuk berinteraksi dan memperoleh umpan balik sehingga siswa dapat mengetahui hasil dari belajarnya secara langsung dan dapat mengerjakan soal yang berbeda-beda. Kebiasaan ini menjadikan siswa tidak pilih-pilih dalam mengerjakan soal sehingga tidak hanya mengerjakan soal yang mudah saja. Hal tersebut sesuai dengan pendapat Haney dan Ullmer (Yusuf Hadi Miarso, 2009, p.462) bahwa karakteristik media interaktif membuat siswa tidak hanya memerhatikan penyajian, atau objek, tetapi dipaksa untuk berinteraksi selama mengikuti pelajaran.
Kesempatan untuk melakukan operasi hitung bilangan bulat pada media visual interaktif menjadikan siswa suka mengerjakan soal/ latihan matematika, lebih perhatian, bersemangat, tidak cepat bosan dan tidak mengeluh saat mendapat tugas dari guru. Hal tersebut menunjukkan bahwa siswa termotivasi dalam belajar.

Peningkatan Prestasi Belajar Aspek Sikap

Siswa yang mempunyai motivasi belajar menunjukkan sikap yang baik dan sesuai selama pembelajaran. Sikap yang dimaksud diantaranya adalah menunjukkan rasa ingin tahu dan bertanggungjawab. Pada saat pembelajaran operasi hitung bilangan bulat menggunakan media visual interaktif berlangsung siswa bersedia mengikuti proses pembelajaran, mengajukan pertanyaan dan menggunakan media untuk mengeksplorasi materi. Hal tersebut sesuai dengan penelitian yang dilakukan oleh Engel (2011, p.643) bahwa tandatandarasa ingin tahusiswa antara lain mau bertanya, mau memperhatikan dan mau menyelidiki. Rasa ingin tahu yang ditunjukkan siswa dapat mempertahankan semangat dalam belajar.

Siswa tidak hanya semangat dalam belajar tetapi juga menunjukkan sikap tanggung jawab terutama saat mengerjakan tugas. Media visual interaktif yang digunakan menyediakan kesempatan untuk siswa dalam berlatih mengerjakan operasi hitung bilangan bulat. Hal ini membuat siswa suka mengerjakan soal. Siswa menunjukkan sikap bersedia menerima tugas. Hal terbukti pada akhir siklus II (pertemuan 3) seluruh siswa dapat menerima tugas dengan baik. Siswa tidak ada lagi yang mengeluh saat mendapatkan tugas dari guru. Siswa juga berusaha mengerjakan tugas secara mandiri sampai mereka menyelesaikannya. Tanggung jawab individu ditunjukkan dengan melakukan pekerjaan secara mandiri dan terus mengerjakan tugas. 
Peningkatan Prestasi Belajar Aspek Pengetahuan

Peningkatan prestasi belajar aspek pengetahuan disebabkan karena pada saat belajar operasi hitung menggunakan media visual interaktif, siswa mendapatkan pengalaman belajar dan pemahaman yang lebih konkret. Hal tersebut sesuai dengan karakteristik siswa kelas 4 SD dimana tahap perkembangannya berada pada tahap operasional konkret (Piaget dalam Schunk 2012, p.223). Dalam tahap ini taraf berfikir siswa didasarkan pada manipulasi objek konkret sehingga media visual interaktif yang dibuat memodifikasi garis bilangan dan benda dua warna.

Siswa menggunakan media tersebut secara langsung untuk mempelajari operasi hitung bilangan bulat. Camara (2013, p.156) menyimpulkan bahwa keterlibatan siswa dengan media interaktif memungkinkan mereka untuk memanipulasi pengetahuan fisik, yaitu ketika siswa terlibat mengeksplorasi berbagai konsep aljabar dan keterampilan dalam lingkungan matematika yang meningkatkan pemahaman tentang konsep-konsep matematika.

Siswa melakukan operasi hitung dan mendapatkan umpan balik kemudian hasilnya dituliskan pada LKS. Selanjutnya, siswa mendiskusikan hasil pekerjaan tersebut bersama teman sekelompoknya untuk mendapatkan kesimpulan. Kesimpulan yang telah diperoleh melalui pengalaman belajar menggunakan media membuat siswa lebih memahami materi sehingga dapat mengerjakan tes dengan baik. Hal tersebut sesuai dengan penelitian Stephan dan Didem (2012) bahwa instruksi menggunakan Vertical Number Line (VNL) membantu siswa secara signifikan dan meningkatkan nilai tes untuk penambahan dan pengurangan. Akan tetapi beberapa siswa melakukan kesalahan pada hasil evaluasi akhir pembelajaran seperti terlihat pada gambar 2 berikut.

$$
\begin{aligned}
& \text { 1. } 15+18=.3 .3 \\
& \text { 2. }(-29)+13=.92 \\
& 3 .(-15)+(-27)=-.42 \\
& \text { A. } 28+(-28)=. .56 \\
& 5.24+17=41
\end{aligned}
$$

Gambar 1. Kesalahan Siswa dalam Mengerjakan Penjumlahan

Dari gambar 2 di atas terlihat siswa belum dapat menentukan hasil penjumlahan dua bilangan bulat dikarenakan kurang memperhatikan bilangannya. Siswa tidak memperhatikan simbol positif dan negatif yang terdapat pada soal. Beberapa siswa juga melakukan kesalahan dalam operasi hitung pengurangan bilangan bulat seperti pada gambar 3 berikut.

$$
\begin{aligned}
& \text { 3) } 24-(-15)=24+\text { a, maka a adalah... } \\
& \text { a. } 51 \\
& \text { b. } 15 \\
& \text { c. }-15 \\
& \text { d. }-51
\end{aligned}
$$

Gambar 2. Kesalahan Siswa dalam Operasi Hitung Pengurangan

Gambar 3 di atas menunjukkan bahwa siswa tersebut belum dapat memahami aturan dalam operasi hitung pengurangan bilangan bulat. Dalam operasi hitung pengurangan bilangan bulat mengurangi sama dengan menambah dengan inversnya. Dari jawaban yang dipilih terlihat bahwa siswa salah menentukan inversnya

Kesalahan tersebut masih terjadi disebabkan oleh beberapa hal, diantaranya adalah adanya siswa yang kesulitan menggunakan laptop saat pembelajaran media visual interaktif dan beberapa siswa yang tidak bersedia menerima teman kelomploknya. Kedua hal tersebut membuat siswa kurang nyaman saat belajar sehingga pengetahuan yang diperoleh juga tidak maksimal. Selain itu, dua siswa tidak 
mengikuti seluruh rangkaian pembelajaran karena sakit. Ada juga siswa yang mengatakan bahwa materi bilangan bulat adalah sulit mungkin karena sifatnya yang abstrak. Letak keabstrakannya dapat dilihat dari bilangan bulat negatif yang jarang digunakan dalam kehidupan sehari-hari sehingga siswa cenderung keliru dalam menentukan hasil penjumlahan maupun pengurangan bilangan bulat (Fredy dan Soenarto, 2013, P.163).

Peningkatan Prestasi Belajar Aspek Keterampilan

Dalam penelitian ini keterampilan siswa diukur dengan penilaian kinerja menggunakan tes prestasi belajar berbentuk uraian. Setiap butir merupakan soal cerita. Siswa diharapkan mempunyai beberapa keterampilan untuk menyelesaikan soal. Keterampilan yang dimaksud adalah (1) menuliskan apa yang diketahui dan ditanyakan dari soal, (2) menentukan kalimat matematika yang sesuai, (3) melakukan perhitungan dan (4) membuat kesimpulan sesuai dengan apa yang ditanyakan. Siswa yang terampil dapat menyelesaikan soal (tugas) dengan tepat. Hal tersebut sesuai dengan pendapat Gagne (Bell 1978, p.108).

Dalam media visual interaktif disajikan contoh masalah yang berkaitan dengan bilangan bulat. Siswa memperhatikan cara penyelesaiannya. Selanjutnya siswa berlatih untuk menyelesaikan beberapa soal dan langsung mendapat umpan balik dari pekerjaannya tersebut.

Media visual interaktif memberikan dukungan terhadap prestasi belajar tentang operasi hitung bilangan bulat pada aspek keterampilan. Media visual interaktif yang digunakan memodifikasi penggunaan garis bilangan dan benda dua warna untuk pengenalan tahap awal tentang bilangan bulat. Ditemukan beberapa gambar garis bilangan dalam lembar jawab siswa seperti halnya yang terdapat dalam media visual interaktif. Beberapa siswa menggambar garis bilangan tersebut untuk memberikan gambaran tentang penyelesaian soal. Hal ini sesuai dengan penelitian Bofferding (2010) bahwa instruksi pada binary (mengeksplorasi konsep penjumlahan dan pengurangan dengan bergerak maju dan mundur pada garis bilangan) dan/ atau makna unary (memainkan dua game pada garis bilangan vertikal dan ditentukan mana dua bilangan bulat lebih besar dan menentukan letak suatu bilangan pada garis bilangan tersebut) dari tanda minus mendukung pemikiran mereka tentang bilangan bulat negatif.

Akan tetapi, untuk beberapa soal berikutnya mereka tidak lagi menggambar garis bilangan karena bilangannya semakin besar. Mereka telah memperoleh pengetahuan yang baik tentang bilangan bulat dan pada akhirnya berpengaruh pada keterampilan yang dimilikinya sehingga tidak menggunakannya lagi. Hal tersebut sesuai dengan penelitian yang dilakukan oleh Pratiwi, Amin, Lukito, dan Van Galen (2010) bahwa para peserta didik dapat memahami konsep angka negatif melalui kegiatan dengan garis bilangan dan dapat dihubungkan dengan konteks yang lebih formal untuk cara belajar angka negatif.

Tayangan media visual interaktif dibuat untuk membangkitkan sikap rasa ingin tahu mereka. Saat siswa memiliki rasa ingin tahu mereka berusaha untuk memenuhi keingintahuannya dengan cara mengeksplorasi materi pada media dengan penuh tanggungjawab. Hal tersebut ditunjukkan dengan sikap mereka yang benar-benar menggunakan media untuk belajar. Saat mengeksplorasi materi dengan media, siswa menggunakan LKS dengan pendekatan saintifik. Dalam pendekatan saintifik siswa mengamati, menanya, mencoba, menalar, dan mengkomunikasikan sehingga siswa dapat menemukan konsep yang sedang mereka pelajari. Hal inilah yang menyebabkan prestasi belajar siswa meningkat. Siswa tidak sekedar menghafal 
sehingga pengetahuan dan keterampilan yang diperoleh lebih mendalam.

\section{PENUTUP}

Simpulan

Setelah dilakukan pembelajaran menggunakan media visual interaktif selama 2 siklus terjadi peningkatan motivasi belajar matematika pada siswa kelas 4 SD Negeri Paliyan IV Gunungkidul. Peningkatan tersebut ditandai dengan bertambahnya jumlah siswa yang mempunyai motivasi belajar dalam kategori minimal baik dari waktu sebelum tindakan sampai pada akhir siklus II. Peningkatan motivasi belajar siswa disebabkan karena siswa dapat berinteraksi secara langsung, mencoba melakukan operasi hitung bilangan bulat dan jika salah dapat mengulangnya sampai benar sekaligus mendapatkan umpan balik. Hal tersebut menyebabkan siswa lebih bersemangat, ulet menghadapi kesulitan dan tidak mudah menyerah sehingga mereka tidak lagi mengeluh saat mendapatkan tugas dari guru. Beberapa hal tersebut merupakan tanda-tanda siswa yang termotivasi dalam belajar.

Selain peningkatan motivasi belajar matematika, setelah dilakukan pembelajaran menggunakan media visual interaktif juga terjadi peningkatan prestasi belajar tentang operasi hitung bilangan bulat pada siswa kelas 4 SD Negeri Paliyan IV Gunungkidul untuk aspek sikap, pengetahuan, dan keterampilan. Tayangan media visual interaktif dibuat untuk membangkitkan sikap rasa ingin tahu mereka. Untuk memenuhi keingintahuannya siswa mengeksplorasi materi pada media dengan penuh tanggungjawab. Saat mengeksplorasi materi dengan media, siswa menggunakan LKS dengan pendekatan saintifik. Dalam pendekatan saintifik siswa mengamati, menanya, mencoba, menalar, dan mengkomunikasikan sehingga siswa dapat menemukan konsep yang sedang mereka pelajari. Hal inilah yang membuat materi tersebut lebih diingat dan dipa- hami siswa sehingga prestasi belajarnya meningkat.

Saran

Berdasarkan kesimpulan hasil penelitian, maka dapat dikemukakan saran kepada berbagai pihak diantaranya guru dan peneliti. Bagi guru, (1) jika ingin membangkitkan dan mempertahankan motivasi salah satu cara yang dapat dilakukan adalah menggunakan media visual interaktif yang menarik, menjadikan siswa lebih aktif, memberikan umpan balik secara langsung dan membuat siswa lebih mandiri. (2) guru hendaknya selalu menggunakan media pembelajaran dalam membelajarkan materi yang bersifat abstrak seperti halnya pada bilangan bulat. (3) untuk mengoptimalkan fungsi dari media visual interaktif sebaiknya jika memungkinkan jumlah komputer dan jumlah siswa adalah sebanding sehingga masing -masing siswa dapat menggunakannya sendiri.

Bagi peneliti lanjutan diharapkan menambah waktu yang digunakan untuk penelitian sehingga selain dapat mengoptimalkan penggunaan media visual interaktif juga dapat memberikan tindak lanjut untuk setiap materi yang diajarkan supaya pemahaman siswa lebih mendalam.

\section{DAFTAR PUSTAKA}

Awan, R.U., Noureen, G., \& Naz, A. (2011). A study of relationship between Achievement motivation, self concept and achievement in english and mathematics at secondary level. International Education Studies vol.4(3),72-79.

Bell, F. H. (1978). Teaching and learning mathematics (in secondary school). Dubuque: Brown Company Publishers

Bester, G \& Brand, L. (2013). The effect of technology on learner attention and achievement in the classroom. South african journal of education 33 (2),1-15.

Briggs, M., Woodfield, A., Martin, C., \& Swatton, P. (2009). Assessment for learn-

Peningkatan Motivasi dan Prestasi Belajar Operasi Hitung Bilangan Bulat Siswa Kelas 4 ... 
ing and teaching in primary schools ( $2^{\text {nd }}$ ed). Exeter: Learning Matters Ltd

Bofferding, L. (2014). Negative integer understanding: characterizing first graders' mental models. Journal for research in mathematics education, 45(2), 194-245.

Brophy, J. (2010). Motivating students to learn ( $3^{\text {rd }}$ ed). New York: Routledge

Broussard, S.C. \& Garrison, M. E. B. (2004). The relationship between classroom motivation and academic achievement in elementary school-aged children. Family and consumer sciences research journal vol. 33(2), 106-120.

Budiharti, B., \& Jailani, J. (2014). Keefektifan model pembelajaran matematika realistik ditinjau dari prestasi belajar dan kreativitas siswa sekolah dasar. Jurnal Prima Edukasia, 2(1), 27-41. Retrieved from http://journal.uny.ac.id/ index.php/jpe/article/view/2642/2197

Camara, P. (2013). Interactive technology and engaging learners in the mathematics classroom. Dissertation Doctor of Philosophy Walden University. Ann Arbor: UMI Dissertations Publishing

Engel, S. (2011). Children's need to know curiosity in school. Harvard Education Review vol. 81 (4), 625-645.

Fredy, F., \& Soenarto, S. (2013). Pengembangan multimedia pembelajaran matematika pada materi bilangan bulat kelas iv sdn lempuyangan i yogyakarta.Jurnal Prima Edukasia, 1(2), 162-172. Retrieved from http://journal.uny.ac.id/index.php/jpe/article/ view/2633/2188

Forgaty, R. (1991). How to integrate the curricula. Palatine:Skylight Publishing

Froiland, J.M., Oros, E., Smith, L., et al. (2012). Intrinsic Motivation to Learn: The Nexus between Psychological Health and Academic Success. Journal of Contemporary School Psychology, vol.16, 91-100.

Hayat, B. (2010). Prinsip - prinsip dan strategi penilaian di kelas. Jakarta: Pusat
Penilaian Pendidikan Balitbang Kemendiknas

Haylock, D. dan Thangata, F. (2007). Key concept inteaching primary mathematics. London: SAGE Publications

Kunandar. (2013). Penilaian autentik suatu pendekatan praktis. Jakarta: PT RajaGrafindo Persada

Mc. Taggart, R. (1991). Action research a short modern history. Geelong, Victoria: Deakin University Press

Majid, A. \& Firdaus, A. S. (2014). Penilaian autentik proses dan hasil belajar. Bandung: Interes.

Menteri Pendidikan dan Kebudayaan. (2013). Pedoman kurikulum 2013.

Menteri Pendidikan dan Kebudayaan. (2014). Peraturan menteri pendidikan dan kebudayaan RI nomor 104

Miarso, Y. (2011). Menyemai benih teknologi pendidikan. Jakarta: Pustekkom DIKNAS

Newby, T. J., Stepich, D. A., Lehman, J. D., Russel, J. D. \& Ottenbreit-Leftwitch, A. (2011). Educational Technology Teaching and learning. New York: Pearson

Pratiwi, W. D. , Amin, Siti M., Lukito, A. et al. (2013). Supporting students' first conception about addition of integers through number line activities for third grade primary school. Proceeding the first south east asia design/development research (sea-dr) international conference, Sriwijaya University, Palembang, 468-476.

Rodgers, D. L. dan Withrow-Thorton, B. J. (2005). The effect of intructional media on learning motivation. International journal of media Vol. 32(4),333-342.

Sardiman, A.M. (2012). Interaksi dan motivasi belajar mengajar. Jakarta: Rajawali Pres

Schunk, D. H., Pintrich, P. R., dan Meece, J. L. (2010). Motivation in education theory, research, and applications. Upper Saddle River: Pearson

Schunk, D. H. (2012). Teori - teori pembelajaran: prespektifpendidikan. (Terjemahan 
Eva Hamdiah dan Rahmat Fajar). Upper Saddle River: Pearson. (Buku asli diterbitkan tahun 2012)

Sikhwari, T. D. (2014). A study of the relationship between motivation, self concept and academic achievement of students at a university in Limpopo Province, South Africa. International journal education science vol.6 (2), 1925.

Smaldino, L., Lowther, D. L. \& Russel, J. D. (2014). Instructional technology and media for learning $\left(10^{\text {th }} \mathrm{ed}\right)$. Edinburg: Pearson

Stephan, M. \& Didem, A. (2012). A proposed instructional theory for integer addition and subtraction.Journal for research in mathematics education 2012, vol. 43, number. 4, page 428-464.

Sudjana, N. \& Rivai, A. (2010). Media pengajaran. Bandung: Sinar Baru Algesindo
Tella, A. (2007). The impact of motivation on student's academic achievement and learning outcomes in mathematics among secondary school students in nigeria. Eurasia Journal of mathematics, science \& technology education vol.3(2), 149-156.

Widyastuti, N., \& Pujiastuti, P. (2014). Pengaruh pendidikan matematika realistik indonesia (pmri) terhadap pemahaman konsep dan berpikir logis siswa.Jurnal Prima Edukasia, 2(2), 183-193. Retrieved from http://journal.uny.ac.id/index. php/jpe/article/view/2718/2268

Widoyoko, E.P. (2012). Teknik penyusunan instrumen penelitian. Yogyakarta: Pustaka Pelajar.

Williams, K. C. \& Williams, C. C. (2012). Five key ingredients for improving student motivation. Research in higher educational journal vol.8, 1-23. 